\title{
Concepts and delimitation of the world's macro-regions
}

\begin{abstract}
The authors focus on the current differentiation of the world and on its cognitive, application and educational frameworks and importance for the present. Macro-regional differentiation of the world has resulted from geographic concepts and it is a foundation for understanding the global development of society. This article evaluates the specific concepts and factors that form concepts of world macro-regions prepared by famous authors. It also presents a methodological approach for macro-regional forming of the world. After a theoretical and methodological introduction there is a discussion of the differentiation of the world entitled "Macroregional differentiation of the world - formation and application." The authors also present their conception of world differentiation and evaluation of the creation macro-regions and their positive and negative influence of the macro-regional differentiation of the world.
\end{abstract}

\section{Keywords}

Regional geography $\cdot$ geography of the world $\bullet$ differentiation of the world • global macro-regions $\cdot$ concepts and factors of regionalization

๑) University of Warsaw - Faculty of Geography and Regional Studies

\author{
J. Anděl1', I. Bičík ${ }^{2}$, J. D. Bláha ${ }^{1}$ \\ J. E. Purkyně University in Ústí nad Labem, \\ Faculty of Science, Department of Geography, \\ Ústí nad Labem, Czechia \\ e-mail: jiriandel@ujep.cz, jd@jackdaniel.cz \\ ${ }^{2}$ Charles University, Faculty of Science, \\ Department of Social Geography and Regional \\ Development, Prague, Czechia \\ e-mail: ivan.bicik@natur.cuni.cz \\ Received: 18 December 2017 \\ Accepted: 19 April 2018
}

\section{Introduction}

Quite considerable attention has been devoted to the topic of macro-regional differentiation of the world, but it is a term which is defined differently by almost everyone. Differentiation of the world is mentioned by the media almost every day, while the divisions used have little if any objective - let alone scientific foundation. There are, for example, the terms Near East, Middle East, Far East and Central Europe. The latter is quite frequently used in Czechia. Alongside those provided by with geographers, various concepts of differentiation of the world are also offered by economists and political scientists as well as linguists and ethnographers. There is the problem that the large majority of the concepts offer their own "original" and "unique" macro-regions. Unfortunately, these concepts mostly lack clear-cut explanations of what methods the individual authors used when delineating their macro-regions. It is astonishing that the topic of regionalization of the world, which is "purely geographic," is not much frequented, and even renowned databases do not offer any comprehensive overview of the literature on the topic. This is why, of the selected concepts of shaping of macro-regions, we stress those in which the technique of their delineation is indicated.

The number of authors dealing with differentiation of the world, including the construction of macro-regions, is quite limited. There is mostly a construction of macro-regions of the world from various viewpoints: political and economic (Häufler 1985), socioeconomic (Morris 1972), sociocultural (De Blij \& Muller 1997; Huntington 1996; Fellmann et al. 2008), or according to technological and economic maturity (Cole 1996).

General ideas behind concepts creating global macroregions

The reasons for a differentiation of the world on the highest regional level or macro-regions differ. These are, in particular, for an "easy understanding" of the division of the global level into bigger, and maximally clearly delineated units that are as internally homogeneous as possible. Depending on the purpose, Polonský \& Novotný (2012) distinguish four alternative types of macroregional differentiation of the world:

1. Academic studies,

2. Textbooks and school atlases,

3. Pragmatic regionalizations (regional reach and administration of "global actors"),

4. Comprehensive regionalizations (popular manuals, databases, thesauruses, bibliographic classifications, etc.).

Unlike the approach taking into account the whole society, differentiation of the world is given surprisingly little attention in professional literature. It is mostly a "by-product" of research focusing primarily on other problems. The discussed authors mostly refer the conclusions of their research, reflections or databases to the differentiation of the world on the macroregional level. For them, the question of the techniques or methods that shape those macro-regions is a secondary affair, or the formation of regions is perceived as an objective fact. These are the publications of a cultural geographic nature (such as that on the dialects of Spanish presented by Gonçalves \& Sánchez, 2014) and an economic nature (Bramall 2008). For example, in the Scopus database one can currently find (August 2017) around 800 records of publication outputs which are described as a regionalization of the world - in the case of social and Earth sciences. However, only some $15 \%$ of them examine real macroregions of the world (Elsevier 2017). Among them, one can also find publications delineating a certain observed region, such as SubSaharan Africa or Central and Eastern Europe (Smętkowski 2013), or a depiction of historical events by means of GIS (Thornton 2012). 
There are frequent regionalizations referenced to meteorology or the sciences dealing with health, morbidity and mortality (such as Shi et al. 2016).

Alongside those of geographers, various concepts of the division of the world are also offered by economists or political scientists, linguists and ethnographers. However, scant attention is devoted to the methods of their shaping and some of them are merely a certain picture of individual authors' mental ideas. Foreign literature dealing with the division of the world into macro-regions does not provide sufficient methodological notes that would explain their construction. This can be exemplified by some textbooks (such as those by Jackson \& Hudman 1990, or Hobbs \& Dolan 2009), but also by the differentiation of the world used by the United Nations, which was devised in order to conduct statistical analyses (United Nations 2012). Here, the world is divided into macro-geographical regions and subregions. Macrogeographical regions are arranged to maximally copy the borders of continents. In total, there are five of them, while America is subdivided into North and Latin America. The continents are subdivided into four or five regions distinguished according to cardinal directions. For example, Northern Europe is created, along with its usual countries, but also including the Baltics and the British Isles. Czechia is classified as a part of Eastern Europe. However, there is also, absurdly, the whole of Russia, which we consider a remnant of the previous delineation of centrally planned economies under the aegis of the USSR (Gorzelak \& Smętkowski 2010).

Cole (1996) describes social and economic development of macro-regions of the world since 1500, which is followed by the global regions themselves, as well as their populations and economies. Above all, the calculations of individual original indicators for individual macro-regions of the world and their share in the world summary are innovative, with a vital importance for educational objectives. In the conclusion, the author presents the chapter "Twenty-first-century Earth," describing the form of the world at the close of the $20^{\text {th }}$ century, with further prospects for the future. Nierop (1989) deals with an analysis of the states with regard to their position in the world. Based on the analysis, there is a definition of macro-regions or the parts of the world with a similar economic level. In the conclusion, the author defines the delineation of macro-regions, such as Western Europe, Latin America, or the "Arab Group," which means a group of Arab states forming a macro-region. As a rule, it is called the macroregion of Northern Africa and South-Western Asia at present.

When it comes to Czech authors, the topic of global differentiation of the world was recently examined especially by Hampl and by Novotný (Hampl 2010, Novotný 2012). Their studies are based on an comprehensive methodological approach enabling a comparison of the importance of certain groups of states and changes in their position in the world. Macro-regions and their construction are specifically targeted by the studies of Polonský (2012) and also by Polonský \& Novotný (2012), which give new impulses to the topic in question. With regard to the application viewpoint, in the teaching of "new regional geography," the available Czech literature includes Macro-regions of the world by Bičík et al. (2010). It seeks to present a hierarchical arrangement of basic information on (macro)regions of the world to secondary school students. This textbook aims to facilitate the understanding of the world or the particular natural, socioeconomic and cultural conditions of the given macro-regions to students. Macro-regions are divided into underdeveloped and developed ones, depending on the degree of their maturity. Among others, the textbook is also devoted to the social and economic development of human civilization and the globalization process, or global risks, as well as crucial world problems in individual macro-regions.

\section{Concepts}

Macro-regions are often created based purely on an evaluation of economic development, which is a problematic approach because it is appropriate to evaluate many other factors and limits. There are political (especially geopolitical) factors, as well as historical, social and cultural ones. In the last two decades, it has been particularly necessary to also evaluate environmental factors or interaction between "nature" and "society" (Hampl 2010). Social and economic factors were researched by Morris (1972) or Häufler (1985), but their approach was influenced by the political character of that time (the division into the capitalist, socialist and third worlds). Social and cultural disposition were researched by De Blij \& Muller (1997), Huntington (1996) and Fellmann et al. (2008), who divided into civilizations (Figures 1-3). Cole (1996) divided the world into 12 big units on the basis of their technical and economic level of development, and also evaluated natural resources, the level of application of modern technologies and volume of capital for domestic and foreign application.

Huntington (1996) distinguishes eight main present-day civilizations (Figure 1), although he does not primarily pursue the objective of differentiating the world. He says that the borders are very vague because a civilization also includes the people who share its culture but who may live in countries with a prevailing population of a different civilization. He understands civilization as the hierarchically highest cultural grouping of people, with such shared elements as history, religion or language, as well as the subjective identification of individual members with a particular civilization. When it comes to basic civilizations, Huntington (1996) cites the Western, Islamic, Hindu (Indian), Chinese (Sinic) and Japanese (these last two sometimes being denoted as Far Eastern civilizations). Other civilizations are not as clear-cut, such as the Buddhist, which has a number of shared elements with the Chinese and Japanese civilizations. Western civilization constitutes Europe (excluding the countries of Orthodox religion), North America and the countries inhabited by Europeans, such as Australia and New Zealand. Western civilization is related to Orthodox (Russian) and Latin American civilizations, which have their own identity, distinguishing them from the West. African civilization is also conceived of as separate. However, Huntington has some doubts about its existence, calling it "probable." In fact, Northern Africa and the eastern coast of the Mediterranean are parts of the Islamic civilization, and Ethiopia is a historical civilization in its own right, while elements of Western civilization appear under the influence of colonialism in other places.

One of the concepts accepted in Anglo-Saxon literature is that of macro-regions of the world according to De Blij \& Muller (1997 and another 16 gradually innovated editions). When devising macro-regions, there is a very good application of the order level here. Their culture realm delineates the biggest and most complex territorial units, which are defined on the basis of similarity of general cultural traditions. Such a unit is exemplified by the Chinese or Latin American realms. Within these culture realms, culture regions are distinguished. Within the framework of Latin America, these might be Brazil or Argentina. There is a similar cultural difference within the Eastern European region and the Southern European (Mediterranean) region. Cultural regions are subdivided into cultural subregions. Canada is an AngloAmerican cultural region and French Quebec is a subregion of Canada's culture realm. When devising a regionalization of the world, these authors conceive the regions very broadly, taking into account the economy, urbanization, and political, physical and historical geography, applying a geographic synthesis based on human geography methods. Using these principles, De Blij and Muller divide the world into ten geographic realms or macro-regions (Figure 2). With regard to the degree of social and economic development, three of them can be denoted as 


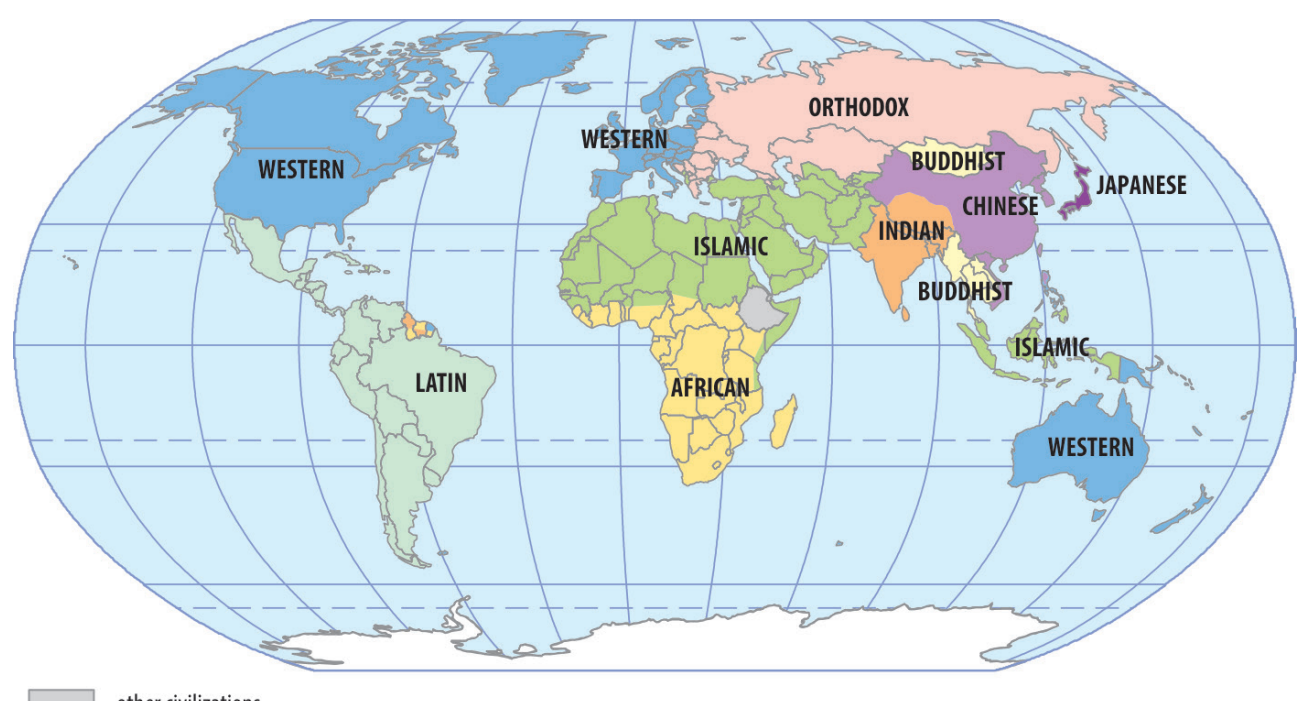

Figure 1. Civilizations according to Huntington (1996). Note: partly modified; scale 1:260,000,000.

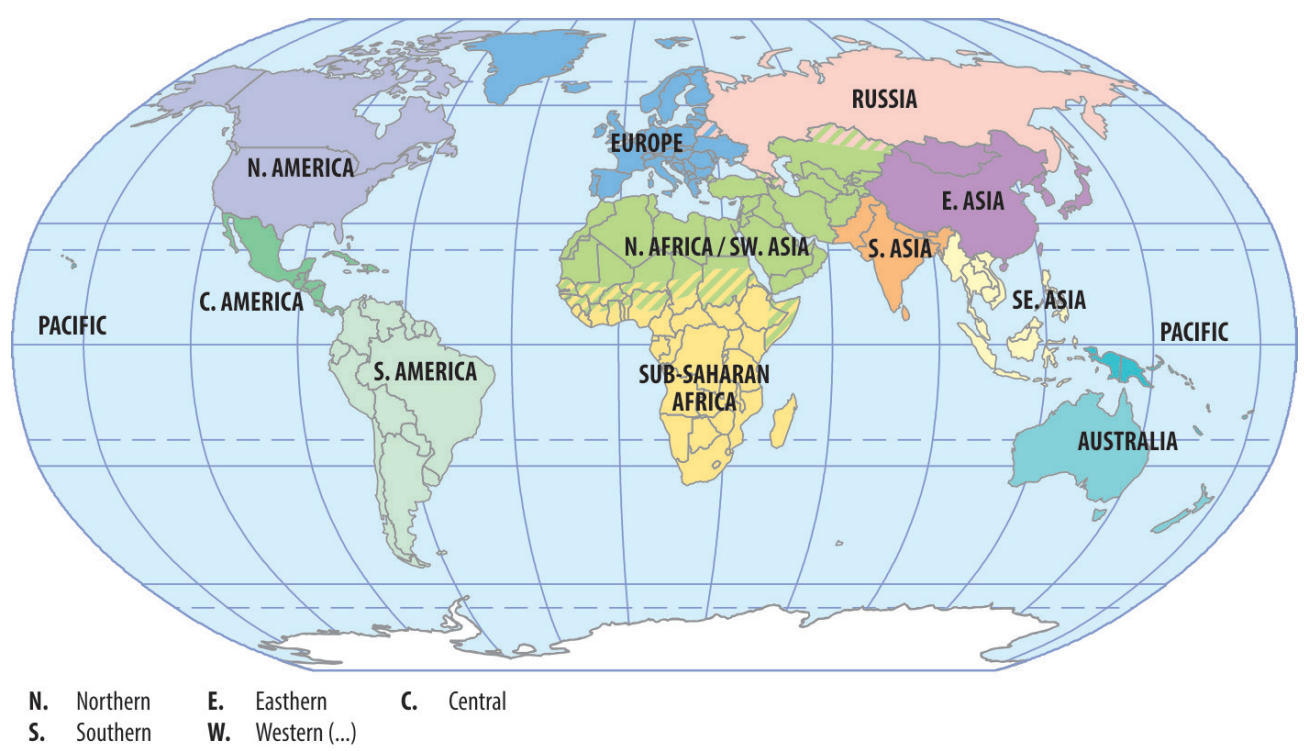

Figure 2. Macro-regions of the world according to De Blij \& Muller (1997). Scale 1:260,000,000.

developed and the remaining three are described by these authors as underdeveloped (developing).

A similar concept was outlined by Bradshaw et al. (2000, 2004), who understand macro-regions as areas with a shared cultural and historical experience. In order to distinguish them, use is made of cultural, economic, political and physical geographic signs. The same foundations are followed up by Fellmann et al. (2008) with the differentiation of the world into 11 macro-regions (culture realms): European (including Greenland), Northern American, Slav (but without Czechia, Slovakia or Poland!), Australian-European (Australia and New Zealand), the Pacific Islands macro-region, Sino-Japanese, Southeast Asian, Indian, Islamic, Sub-Saharan African and Latin American (Figure 3).

From among Czech geographers, Novotný (2003) dealt with a concrete delineation of macro-regions of the world, although in the study in question the topic was not his primary objective. He is one of the few to present a comprehensive idea of the way in which such a construction should proceed. When devising his regionalization, he outlined the following principles. Macroregions should be mutually comparable in terms of the size of their area and population (this idea was earlier applied by Korčák, 1938, 1973), if possible with a contiguous territory. Above all, they should be as organic as possible with regard to the relationship between the node and periphery, social and economic maturity and cultural integrity (Polonský 2012). He differs from other authors especially in his effort to differentiate the world into macroregions (subsystems) of approximately equal size. He defined twelve of them, having always divided America and Africa into fairly comparable units. America is divided into the Canadian, American, Brazilian and Latin American subsystems and Africa into the South African, Central African and Islamic subsystems. The latter also reaches into Western Asia. 


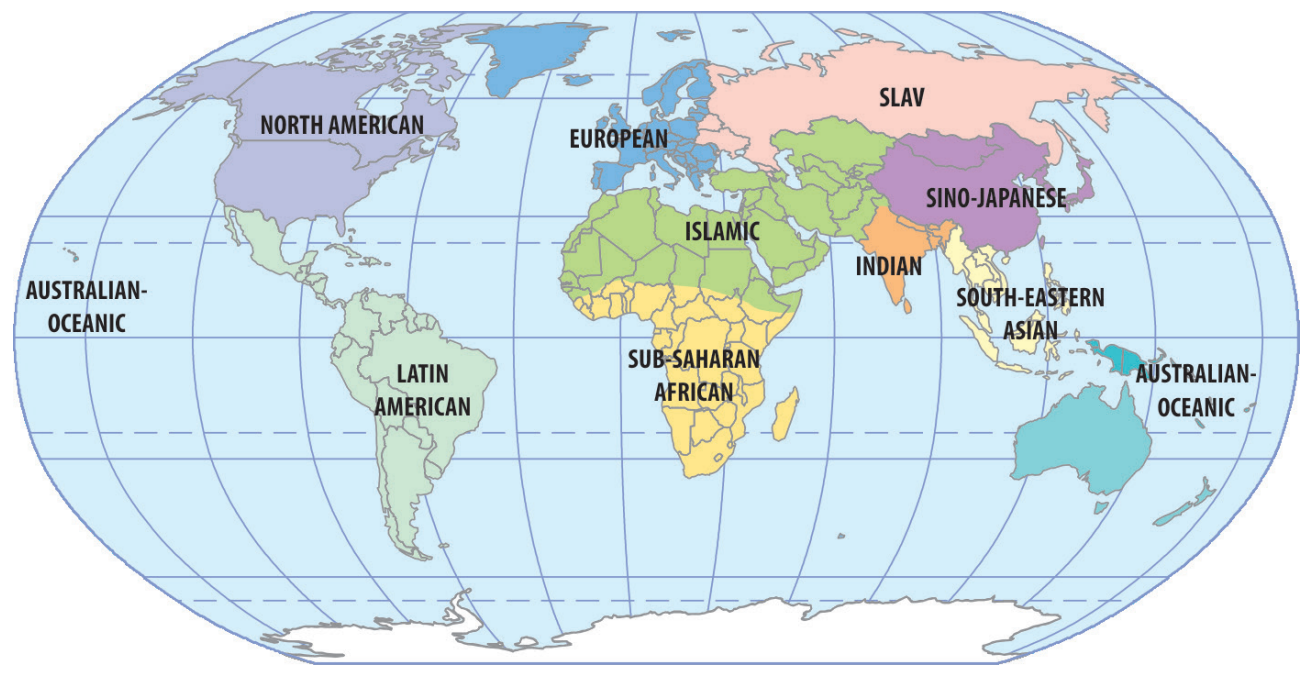

Figure 3. Culture realms according to Fellmann et al. (2008). Scale 1:260,000,000.

\section{Conclusions}

Individual concepts of regionalization of the world differ not only in their delineations, but also in the number and names of the devised territorial units (Table 1). The most (fifteen macro-regions) are delineated by Morris (1972), and the least (eight) by Clawson et al. (2007). (We see a similar number created by Huntington if we take into consideration his "crudest" delineation.) The names used for macro-regions are also interesting. Mostly, use is made of the names arising from the concept of continents and referring to delineation primarily according to cardinal directions (such as Morris 1972, or Clawson et al. 2007). There are also political names (such as post-Communist Europe, by Cole 1996), which can be considered suitable at present, and civilization names primarily reflecting the existence of a prevailing religion in a given macroregion (Huntington 1996 in particular). With its terminology for macro-regions, our concept is closest to that of Fellman et al. (2008). However, we try more consistently to insist on a uniform "style" of terminology, which is comprehensible and unmistakable for readers; we suggested one half of them according to the major state (according to its economic and political strength) of a given macro-region (Russian, Indian, Indonesian, etc.). We name the rest of the macro-regions according to the dominant civilization (or also culture and predominant language group) that is situated there (such as the Islamic or Latin American macro-regions).

Table 1 examines the concepts of individual authors of macro-regionalizations of the world, offering a certain framework comparison. For the sake of lucidity, we classify the individual macro-regions according to individual continents. Partial territorial units are commonly denoted by a symbol $(\times$ or *) indicating the affiliation of these units within the framework of a single macroregion: e.g., * for Russia and Central Europe or $\times$ as Western civilization with a reach into Europe, North America, Australia and Oceania. Similarly, most concepts link South-Western Asia with Northern Africa. We deliberately do not mention the concept with which the Organization of United Nations works, as it considerably differs from the regionalizations mentioned here, being instead a set of "randomly" selected neighboring states.

According to the various concepts, the biggest differences are especially noted in Europe and Asia. In older works drafted at the time of a bipolar world there was the apparent influence of the "Iron Curtain," which divided Europe into two parts (Häufler 1985), or the concepts outlined the region of "peninsular" Southern
Europe, with specific cultural features (the influence of ancient Greece and Rome) and specific political and economic features (Morris 1972). Subsequent concepts capture the integrating Europe as a single whole, with the exception of Huntington, who still sees historical differences between Catholic and Protestant Europe on the one hand and Orthodox Europe on the other.

In the latest concepts, the Russian macro-region has lost the former Soviet republics (with the exception of Clawson, who adds Central Eurasia to Russia). We also embrace this concept, but we call the macro-region "Russian," unlike the problematic name "Slav," used by Fellmann et al. (2008). South-Western and Southern Asia are mostly delineated in the same way, with the integrating factor of Islam or Hinduism (Indian civilizations) or a relatively analogous development and affiliation with "British India." Few if any problems are caused by the delineation of South-Eastern Asia, which we denote as the Indonesian macro-region. Here we highlight the fact that some authors merge South-Eastern Asia and Australia with Oceania in a single whole (e.g., De Blij \& Muller 1997). The situation is more complicated according to the concept of Huntington, who divides it into two parts: Buddhist and Islamic. Some concepts (Huntington 1996, Häufler 1985) separate Japan from Eastern Asia. We call this macro-region Sino-Japanese according to its "leading" states. The latter three macro-regions are merged by Clawson (2007) in a single whole under the rather misleading name "Asia."

The situation is relatively consistent in Africa, which is divided into the Sub-Saharan and Islamic macro-regions. However, the border between the Islamic and African macro-regions (Sub-Saharan Africa) is delineated quite differently. Only Morris (1972) divides the large area of North America into three macroregions, while in the rest of the concepts it is a single whole. With the exception of Clawson's and Huntington's divisions, Latin America is divided into Central and South America, but some authors single out the Caribbean islands as a separate unit. Australia constitutes a single macro-region, with the exception of Huntington who includes Australia itself and New Zealand in Western civilization.

The assessment of individual concepts results in a number of facts. Their change over time is quite specific. The first concepts were politically focused and reflected the bipolar state of the world at that time (Morris 1972 and Häufler 1985). The concept that responds to the tension in the world is based on the principle 
MISCELLANEA GEOGRAPHICA - REGIONAL STUDIES ON DEVELOPMENT

Vol. $22 \cdot$ No. $1 \cdot 2018 \cdot$ pp. 16-21 •ISSN: 2084-6118 • DOI: 10.2478/mgrsd-2018-0001

Table 1. Macro-regions of the world in various authors' concepts

\begin{tabular}{|c|c|c|c|c|c|c|c|}
\hline Author & MORRIS & HÄUFLER & \begin{tabular}{|c|} 
DE BLIJ \\
and MULLER
\end{tabular} & $\begin{array}{l}\text { CLAWSON } \\
\text { et al. }\end{array}$ & $\begin{array}{l}\text { HUNTINGTON } \\
\text { (civilisations) }\end{array}$ & COLE & FELLMANN et al. \\
\hline Year & 1972 & 1985 & 1997 & 2007 & 1996 & 1996 & 2008 \\
\hline \multirow{4}{*}{ Europe } & \multirow{2}{*}{$\begin{array}{c}\text { Western } \\
\text { and Central }\end{array}$} & Capitalist & \multirow{4}{*}{ Europe } & \multirow{4}{*}{ Europe } & ×Western & "Western" & \\
\hline & & Communist & & & ${ }^{* * *}$ Orthodox & $\begin{array}{c}\text { post- } \\
\text { Communist }\end{array}$ & European \\
\hline & Southern & & & & & & \\
\hline & Eastern & & & & & & \\
\hline Russia & USSR & USSR & Russia & ${ }^{*}$ Russia & ${ }^{* * *}$ Russia & $\begin{array}{l}\text { post-Soviet } \\
\text { space }\end{array}$ & Slav \\
\hline \multirow{5}{*}{ Asia } & ${ }^{* *}$ Middle East & ${ }^{* *} \mathrm{SWAs}+\mathrm{NAf}$ & ** SWAs +NAf & $\begin{array}{l}{ }^{*} \text { Central } \\
\text { EurAsia }\end{array}$ & ${ }^{* *}$ Islamic & ** SWAs +NAf & ${ }^{* *}$ Islamic \\
\hline & Southern & Eastern & Eastern & ${ }^{* *}$ Central & Indian & Southern & Indian \\
\hline & $\begin{array}{l}\text { South- } \\
\text { Eastern }\end{array}$ & Southern & Southern & Eastern & Buddhist & South-Eastern & South-Eastern \\
\hline & Central & $\begin{array}{c}\begin{array}{c}\text { China, North } \\
\text { Korea }\end{array} \\
\end{array}$ & $\begin{array}{l}\text { China, North } \\
\text { Korea }\end{array}$ & & Chinese & $\begin{array}{c}\text { Eastern } \\
\text { developing }\end{array}$ & Sino- \\
\hline & and Eastern & Japan & Japan & Asia & Japanese & $\begin{array}{c}\text { Eastern } \\
\text { advanced }\end{array}$ & Japanese \\
\hline \multirow{2}{*}{ Africa } & ${ }^{* *}$ Middle East & ${ }^{* *} \mathrm{SWAs}+\mathrm{NAf}$ & **SWAs+NAf & ${ }^{* *}$ Middle East & ** Islamic & ${ }^{* *} \mathrm{SWAs}+\mathrm{NAf}$ & ${ }^{* *}$ Islamic \\
\hline & Sub-Saharan & Sub-Saharan & Sub-Saharan & Sub-Saharan & African & Sub-Saharan & Sub-Saharan \\
\hline \multirow{3}{*}{$\begin{array}{l}\text { North } \\
\text { America }\end{array}$} & Canada & \multirow{3}{*}{ North } & \multirow{3}{*}{ North } & USA & & & \\
\hline & USA-West & & & Canada & $\times$ Western & North & North American \\
\hline & USA-East & & & & & & \\
\hline \multirow{2}{*}{$\begin{array}{l}\text { Latin } \\
\text { America }\end{array}$} & Central & Central & Central & \multirow{2}{*}{ Latin America } & Latin & Latin & Latin \\
\hline & South & South & South & & & & American \\
\hline \multirow{2}{*}{ Australia } & \multirow{2}{*}{ Australia } & \multirow{2}{*}{ Australia } & Australia & \multirow{2}{*}{ Australia } & $\times$ Western & \multirow{2}{*}{$\begin{array}{c}\text { Australia } \\
\text { and Oceania }\end{array}$} & Australian-Oceanic \\
\hline & & & Pacific & & & & \\
\hline $\begin{array}{l}\text { All macro- } \\
\text { regions }\end{array}$ & 15 & 13 & 12 & 8 & 8 & 12 & 11 \\
\hline
\end{tabular}

Notes: In some complicated cases, there is a simplified concept. The signs * or ** depict being part of two continents, SWAs+NAf representing South-Western Asia and Northern Africa. Sources: Morris 1972, Häufler 1985, De Blij and Muller 1997, Clawson et al. 2007, Huntington 1996, Cole 1996, Fellmann et al. 2008

of civilizations and the historical context of their development (Huntington 1996). Geographers who emphasize the hierarchical approach to macro-region creation seek to link social, cultural and economic approaches (De Blij \& Muller 1997, or Clawson \& Airriess 2007). These comprehensive approaches are also the basis for the concept that will be prepared by the authors of this article for another issue of the journal.

To conclude, one can state that from the overview of regionalization of the world one can see obvious differences in its concepts. The political concepts primarily correspond with the time they were outlined. The point of departure of their regionalization can also be seen in the reasons for their construction and message being political, economic, social or cultural. The scale levels of the resulting macro-regions are differentiated, from "non-contiguous territorial units" (such as parts of Europe, North America and Australia) down to a single state (such as Japan in Huntington's concept, 1996). 
Bičík, I, Anděl, J, Havlíček, T \& Matějček, T 2010, Makroregiony světa, Nakladatelství České geografické společnosti, Prague.

Bramall, C 2008, 'Development of local financial systems in mainland China', Eurasian Geography and Economics, vol. 49(2), pp. 160-179.

Bradshaw, M 2000, World Regional Geography: The New Global Order, McGraw-Hill, New York.

Bradshaw, M, White, GW, Diamond, JP \& Chatko, J 2004, Contemporary World Regional Geography: Global Connections, Local Voices, McGraw-Hill, New York.

Clawson, X \& Airriess, ChA 2007, World Regional Geography: A Development Approach, Prentice Hall, Cloth.

Cole, J 1996, Geography of the World's Major Regions, Routledge, New York.

De Blij, HJ \& Muller, PO 1997, Geography: Regions and Concepts, Wiley, New York.

Elsevier 2017, Scopus. Available from: <http://www.scopus. com>. [11 January 2018].

Fellmann, JD, Getis, A \& Getis, J 2008, Human Geography: Landscapes of Human Activities. McGraw-Hill, New York.

Gonçalves, B \& Sánchez, D 2014, 'Crowdsourcing dialect characterization through twitter', PLoS One, vol. 9(11), pp. 1-6. Available from: <http://journals.plos.org/plosone/ article $?$ id $=10.1371 /$ journal. pone.0112074>. [11 January 2018].

Gorzelak, G \& Smętkowski, M 2010, Regional development dynamics in Central and Eastern European countries. Routledge, London.

Hampl, M 2010, 'Globální systém: stav, současné tendence a možné perspektivy distribuce mocenského potenciálu', Geografie, vol. 114(1), pp. 1-20.

Häufler, V 1985, 'K socioekonomické typologii zemí a geografické regionalizaci Země', Sborník ČSGS, vol. 90(2), pp. 135143.

Hobbs, JJ \& Dolan, A 2009, World regional geography, Brooks/ Cole, Belmont, CA.
Huntington, S 1996, The Clash of Civilizations and the Remaking of World Order, Simon and Schuster, New York.

Jackson, RH \& Hudman, LE 1990, World Regional Geography, Wiley, New York.

Korčák, J 1973, Geografie obyvatelstva ve statistické syntéze, Univerzita Karlova, Prague.

Korčák, J 1938, Deux types fondamentaux de distribution statistique. Comité d'organisation, Bull. de l'Institut International de Statistique, Prague.

Morris, JW 1972, World Geography. McGraw-Hill, New York.

Nierop, T 1989, 'Macro-regions and The Global Institutional Network, 1950-1980', Political Geography Quarterly, vol. 8(1), pp. 43-56.

Novotný, J 2003, 'Sociogeografická diferenciace současného světa', Geografie, vol. 108(1), pp. 14-35.

Polonský, F 2012, Makroregionálne struktury světa: reprezentácie, percepcie a objektivizácie. Dissertation. Charles University, Prague.

Polonský, F \& Novotný, J 2012, 'Vnímání sociálněgeografických makroregionů světa', Geografické rozhledy, vol. 21(3): pp. 16-17.

Shi, P et al. 2016, 'World Regionlization of Climate Change (1961-2010)', International Journal of Disaster Risk Science, vol. 7(3), pp. 216-226.

Smętkowski, M 2013, 'Regional Disparities in Central and Eastern European Countries: Trends, Drivers and Prospects', Europe-Asia Studies, vol 65(8), pp. 1529-1554.

United Nations 2012, Standard Country or Area Codes for Statistical Use, Statistical Services Branch Statistics Division United Nations, New York, Available from: <http://unstats. un.org/unsd/methods/m49/m49.htm>. [11 January 2018].

Thornton, PM 2012, 'Mapping dynamic events: Popular contention in China over space and time', Annals of GIS, vol. 18(1), pp. 31-43. 